\title{
SYNONYMY AND POLYSEMY IN LEGAL TERMINOLOGY AND THEIR APPLICATIONS TO BILINGUAL AND BIJURAL TRANSLATION
}

\author{
MARTA CHROMA \\ chroma@prf.cuni.cz \\ Charles University Law School, Praha, Czech Republic
}

\begin{abstract}
The paper focuses on synonymy and polysemy in the language of law in English-speaking countries. The introductory part briefly outlines the process of legal translation and tackle the specificity of bijural translation. Then, traditional understanding of what a term is and its application to legal terminology is considered; three different levels of vocabulary used in legal texts are outlined and their relevance to bijural translation explained. Next, synonyms in the language of law are considered with respect to their intension and distribution, and examples are given to show that most expressions or phrases which are interchangeable synonyms in the general language should be treated carefully in legal translation. Finally, polysemes in legal terminology are discussed and examples given to illustrate problems potentially encountered by translators.
\end{abstract}

Key words: law, bijural translation, legal terminology, synonymy, polysemy

\section{Introduction}

My experience in the language of law started to be shaped in the late 1980s when I became a teacher of what was called "legal Russian" and was expected to teach law students to understand legal texts written in Russian. Although a linguist by education with just lay awareness of law I was supposed to explain to students of Czech law both linguistic and legal peculiarities of Russian legislation and assigned to translate legal texts; any hesitation on my part was withered with the compelling "You can speak Russian, can't you?". It was a general understanding of that time (at least in our part of the world) that the only qualification a teacher or translator must possess was a proficient command of a foreign language. Twenty five years later, not only the new research field of comparative legal linguistics is well-established, but also the awareness of the semiotic nature of processes underlying the study of legal languages and interlingual legal translation arose: linguists consciously explore the law in order to identify the specificity of the language, and more and more lawyers recognize the importance of their excellent linguistic competence as a pillar for their excellent legal skills. A closer cooperation between lawyers and linguists helps discover, identify and describe the cross-cultural meaning of the law, which not only leads to its better understanding but also to its efficient application. The topic of my paper is embedded in linguistic and legal 
semantics but exceeds its realm as translation of legal terminology tackles the issues of legal interpretation, just an inch from legal philosophy in general.

\section{Translation in legal settings}

Legal English has been subject to a more consistent investigation and research since 1963 when Professor Mellinkoff published his book $(2004,1963)$ with quite a challenging aim to rationalize the language of the law in order to make it more comprehensible not only to the lay audience (e.g. clients) but also to avoid unnecessary ambiguity causing misunderstanding even between lawyers. The academic and scholarly interest in the English language as the dominant language in many translations of law not only in the field of public international law but also in private law in the globalized market (Cao 2007: 4) has gradually spread to other legal languages. Comparative jurists encountered legal and linguistic problems first, trying to establish parallels, similarities or differences between legal systems expressed in different languages; to name one, the work of Professor de Groot deserves special recognition in this context since his academic and research interest has spanned the law, legal languages and translational legal lexicography for almost thirty years. The multilingual European Union with its autonomous legal system and legislation binding on all 27 member states published in 23 languages gave rise to a more intensive research into the languages of the law trying not only to unify the whole system of law but also the languages in which the system is conveyed to its users. ${ }^{1}$

As early as in 1959 Roman Jakobson laid down the fundaments of the theory of translation based on his semiotic and functional approach to languages. Understanding translation as interpretation, Jakobson (1959: 232) distinguishes intralingual translation or rewording in the same language; interlingual translation or translation proper between two or more languages; and intersemiotic translation or transmutation is an interpretation of verbal signs by means of signs of nonverbal sign systems. Paraphrasing Jakobson I would call the intralingual translation "interpretation proper" as this is the stage when the translator tries to identify the message (in its widest sense including the form, content and functions) to be conveyed, to understand it and possibly to reword it should such rephrasing help transfer it into the target language. Jakobson's translation proper is transmission across the temporal, geographic, and linguistic boundaries.

Intralingual translation in Jakobson's terminology creates the initial, but crucial or even critical, stage of interlingual translation as the translator may transmit to another language only such information that he or she finds in the source text, i.e. how he or she can interpret the source text at its individual levels as well as in its complexity as a type of (social) discourse. The interpretive theory of translation was developed by the French École Supérieure d'Interprètes et de Traducteurs almost forty years ago (Lederer 2003) and during those years spread over to other training centres for translators and

\footnotetext{
${ }^{1}$ National legal systems of EU Member States have witnessed Europeanization even of the whole private law, not only in contract law (Lando-Beale 1995) but even in tort law as the most "culturally specific" branch of law ("The Principles of European Tort Law" available at http://www.ectil.org).
} 
interpreters; its basic premise is that understanding the source text (ST), i.e. interpreting ST using one's linguistic, extra-linguistic and encyclopaedic knowledge, requires that context be considered at all levels of the meaning construction (word/phrase, sentence, text). The interpretive model of translation sharply contrasts with decontextualized literal translation tending to replace one word in ST with its "dictionary" equivalent regardless of the context of the whole message or even irrespective of the co-text (immediate grammatical surrounding of the word). The terms word-based and sense-based may be used for literal and interpretive translations respectively (Malmkjaer 2005: 6).

Bilingual translation is interactive communication; as social interaction it is a type of discourse fully dependent on a go-between or intermediary - the translator. Explaining the six main functions of a language ${ }^{2}$ and describing unilingual verbal communication Jakobson (1960: 353) emphasizes the context known to both the addresser and the addressee, their common code and physical and mental connection enabling them to interact. His description may be visualized as follows, with the double-ended arrow suggesting that the contact between the addresser and addressee may be reciprocal or interactive in order to facilitate their efficient communication, i.e. their exchanging of understanding:

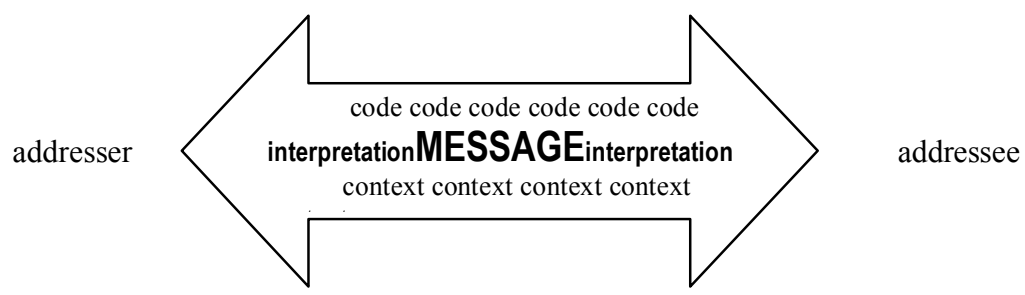

Traditionally, the translator intervenes in communication between the addresser and the addressee where the code, and often the context, used by the former is unknown to the latter but their communication should be facilitated for various reasons. Placing an emphasis on the presumed function of the target text (not its actual perception by the recipient), which predetermines the translation strategy (i.e. approaches, methods and procedures), has prevailed recently. Trosborg (1997: 151) refers to Nord's extended "skopos" theory ${ }^{3}$ applied to translation (Nord, 1991: 8); Nord claims that a translation must fulfill certain requirements, which are defined by translation "instructions" (assignments) in order to be suitable for a certain purpose. Simplistically described, the translator as a communication intermediary first becomes a substitute addressee and after his "processing" the original message he acts as a substitute addresser to convey the "processed" message to the presumed original addressee. The "processing" phase is composed of several steps to take: first the translator tries to understand and interpret (decode) the source language message in its context; then he transmits the interpreted message to the target language (the code of the final addressee); finally, the translator should adapt the transmitted information in a way corresponding to the purpose of

\footnotetext{
${ }^{2}$ i.e. referential, emotive, conative, poetic, phatic and metalingual.

${ }^{3}$ The skopos theory was introduced by Hans J. Vermeer in 1978; the title of his article is Ein Rahmen für eine allgemeine Translationstheorie, and it is available in Aufsätze zur Translationstheorie, published in Heidelberg 1983.
} 
translation, the function of the target text and possibly to the expectations of the ultimate addressee.

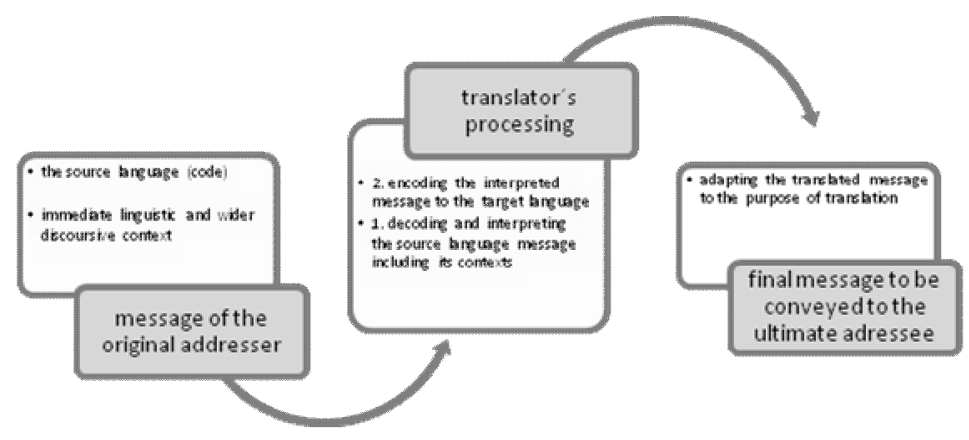

Chart 2

It should be noted, however, that the "contact" between the addresser and the addressee in Jakobson's sense, i.e. the communication channel, is far from being straightforward if the communication is mediated by a translator. Transmission of the original message to the ultimate recipient may span centuries, with substantially different cultures finding themselves at various stages of their development and remote linguistic codes built upon incongruent means of construing social realities. This may leave us slightly incredulous of the potential of interlingual translation as "[...] we cannot simply construct versions of other people's central terms as if we could understand them perfectly. [...] we have to recognize that the most we can attain is an imperfect understanding and approximation." (White 1994: 44).

Law establishes a very specific environment for transmission of information: in the widest sense of the term, its primary purpose is to regulate the life of a specifically identified and possibly defined community. Language is the most important vehicle of communicating law as other sign systems, such as icons, colours or sound, play a marginal role. Since Jakobson's era, the concept of intersemiotic translation has acquired wider dimensions for translating law, particularly in relation to the development of legal semiotics as an extension to legal theory: law may be regarded as a dual semiotic system composed of the language in which it is expressed and the discursive system expressed by that language (Jackson 1997: 3). Interlingual translation of a legal text is intersemiotic translation (Tomášek 1991: 147) as it represents a process where one dual semiotic system should be replaced by the other preserving the purpose and characteristics of the source text to the extent expected and required by the recipient of the translation (the extent may differ depending on the purpose of the translation). The core factor of the interlingual legal translation is the translator's ability to reasonably interpret the source text, i.e. to carry out an "intra-language translation" identifying, for example, the genre of the legal discourse, the genre of the source text (text-type), its narrative repertoire, legal concepts and their reflection in terminology, etc. Only then may the translator transmit the interpreted information into the target language trying to re-create the text in the other legal and linguistic environment keeping in mind the purpose of translation and the expectations and needs of the ultimate recipient. This is the context which the 
Canadian Government calls "bijuralism”. Canadian Legislative Bijuralism was officially launched ten years ago although the first attempts to raise awareness of the tight interconnection between "drafting", "interpreting" and "translating" between the two Canadian legal systems occurred in the 1970s (White 1994: 243). ${ }^{4}$ Strictly speaking, any translation of a legal text may be called bijural since there is always a difference in the source legal and linguistic environment and background and the target legal and linguistic environment and background.

The following chart attempts to schematize a rather complex process of bijural translation built and fully dependent upon the translator's decoding/encoding and interpretive skills; should source law and target law be replaced by source culture and target culture respectively, the chart sketches the process of any intersemiotic translation trying to transpose the culturally rooted message contained in the source text to the target text reflecting on the original cultural rootedness.

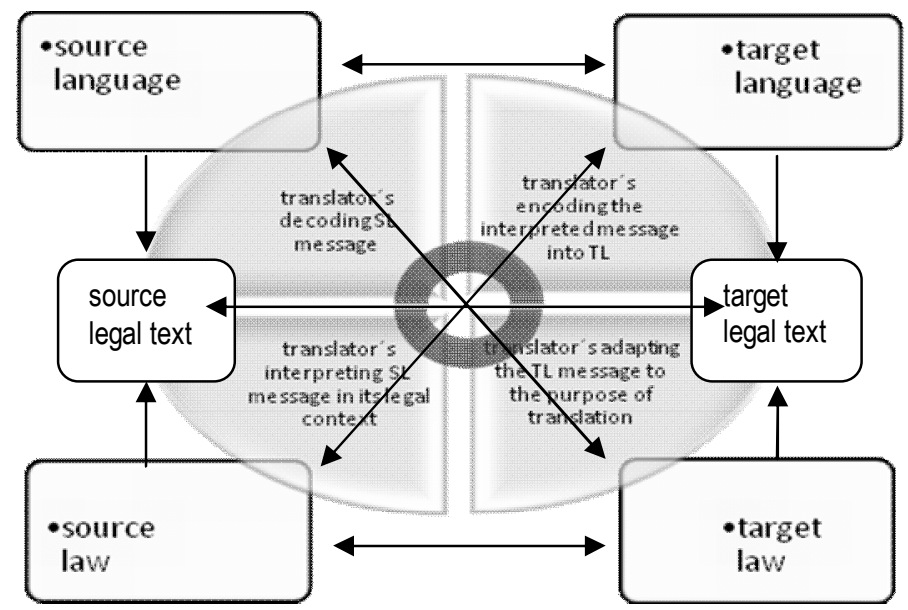

Chart 3

\section{Concepts and terms}

The language of law is classified in various ways and one may speak of a language for special or specific purposes, or of a sublanguage, scientific language, or specialized language (Pearson 1998: 28). Widdowson (1979: 24) characterizes such subcategories of

\footnotetext{
${ }^{4}$ The purpose of the bijural revision of Canadian federal legislation is "to examine statutes and regulations to ensure that they are consistent with both civil law and common law, in both official languages," in order to assist interpretation and drafting of Canadian federal legislation stemming from common law and written in English in the province of Quebec, whose legal system is built upon continental law and written in French. For more information see http://canada.justice.gc.ca/eng/bijurilex/index.html
} 
a language "not as formally defined varieties of English, but as realizations of universal sets of concepts and methods or procedures which define disciplines or areas of enquiry independently of any particular language." This is what Sinclair (2007: 34) calls local grammar describing the specificity of the language in a particular subject area, and what Jackson (1997: 111) terms legal grammar when analyzing the semiotics of legislative texts.

In general understanding what is "legal" about the language of law is usually confined to legal vocabulary, sometimes referred to as "technical words" although terminology as part of vocabulary in legal texts creates no more than one third of the narrative of any legal text and its quantity varies in different text-types as suggested in our earlier research (Chromá 2008: 311).

Semanticists (Cruse 1991: 35, 49; Saeed 2003: 56-57, Murphy 2008: 15, Halliday 2004: 2, Hoey 2006: 156) distinguish between word (as an independent unit for paradigmatic and morphological purposes) and lexical unit (having not only a particular form but also a particular sense). ${ }^{5}$ As word in this narrower sense can hardly be a unit of translation we will use it in its wider sense and interchangeably with lexical unit. What will be strictly distinguished, following Löbner 2002: 20-21, is concept for mental description or meaning and term for its spelling (or sound) form.

Vocabulary used in law can be classified from different perspectives. Mellinkoff (2004: 11) groups the vocabulary into eight categories (common words with uncommon meanings /prayer as a form of pleading/, Old English and Middle English words /witnesseth/, Latin words and phrases /lex fori/, words of Old French and Anglo-Norman origin /plaintiffl, terms of arts /fee simple/, argot /taking the fifth/, ${ }^{6}$ formal phrases lapproach the bench/, and lexical units with flexible meanings /reasonable/).

Another classification (Riley 1995: 73-79) distributes the legal lexicon among three wider groups:

(1) "Pure" legal terminology as relatively a scarce group of lexical units or phrases (such as legal maxims) that are not used outside the branch of law unless stylistically marked. Examples are 'detinue' (as the act of detaining or withholding of what is due) or 'asportation' (the action of carrying off). This category usually includes Old and Middle English words, ${ }^{7}$ and Latin lexical units and phrases.

(2) Legal terminology found in everyday speech: these are lexical units with related legal meaning, such as 'land', 'negligence' or 'law'.

(3) Everyday words which are assigned a special connotation in a given legal context; this often happens when a word or phrase regularly and primarily used in common speech becomes a part of the subject-matter of a statute thus acquiring new semantic dimensions either expanding or narrowing their original meaning. For example, the British Animal Welfare Act 2006 defines animal as "a vertebrate

\footnotetext{
${ }^{5}$ Löbner (2002: 40) calls expressions with a lexical meaning lexems or lexical items and for Murphy (2008: 144) a lexical unit is instantiation of a lexical item.

${ }_{7}^{6}$ Legal jargon is usually used in the same meaning today.

7 This group includes adverbial expressions traditionally called here words (herein, hereof, heretofore), where words (whereas, whereby) or there words (thereat, thereby, therewith) "usually thrown in gratuitously to give legal documents that musty legal smell." (Garner 1995: 401)
} 
other than man" but, under certain circumstances, the Act allows for the expansion of the concept to "include invertebrates of any description".

Hughes \& Alcaraz (2002: 16-18) assign the same three groups of legal vocabulary slightly modified names preserving their characteristics as suggested by Riley above: (1) purely technical terms (meaning the lexical units and phrases found only in the legal setting, i.e. having no application outside law); (2) semi-technical or mixed terms, and (3) everyday vocabulary frequently found in legal texts. It should be noted that the border between (1) and (2) in the latter classification is more relaxed than that of Riley above. ${ }^{8}$ Moreover, as Phillips points out (2003: 48), “[...] many words appear in ordinary speech before importation into the discourse of the law. Many also make the return journey or even a single journey starting from legal language to the ordinary vocabulary." And he adds that "in crossing over in either direction [legal language $\leftrightarrow$ natural language] words and phrases undergo semantic transformation". This is what a translator should always bear in mind. It seems to be quite apparent, and our own practical experience in legal translation suggests so, that the second category encompassing specialised vocabulary acquiring its precise legal meaning in a particular legal context is the most difficult for a translator to tackle and transmit into the target text properly. Unlike the first category encompassing lexical units "looking legal" at first sight, the second group includes units very often concealing their actual legal sense under the veil of their common meaning applicable to the general language (see discovery in Example 1 below).

Another relevant issue in terminology analysis is whether legal terms are monosemous (having one meaning) and at the same time mononymous (consisting of one word) as recommended by Thomas (1993: 46). A rough estimate of entries under letter $\mathrm{P}$ contained in the Black's Law Dictionary $\left(9^{\text {th }}\right.$ ed., pp. 1217-1357) suggests that the proportion of one-word terms and multi-word terms is 20 and $80 \%$ respectively. ${ }^{9}$ Moreover, many multi-word terminological phrases have more than one legal meaning and their exact meaning in a particular context is sometimes quite hard to identify (e.g. the translation of legal remedy in general legal contexts and in the context of the law of equity would require different equivalents to reflect the distinction between common law and equity).

Although translation of a legal text is a multifarious process as suggested in Chart 3 , and interpretation of the source text naturally spans all levels of the text construction and its contexts, the crucial issue for any translator is to identify what lexical units in the text are legal terms designating special legal concepts, what lexical units express the formality of the text and not necessarily its legal substance and what lexical units belong to the general language thus not commonly susceptible to mistaken interpretation. Although there are many definitions of what a term is as suggested by Pearson in her analysis (1998: 9-40) the burden of determining a particular lexical unit to be a term in the particular text would always rest upon the translator. It is much more difficult to identify what a term is in the legal setting since legal terminology does not confine to

\footnotetext{
${ }^{8}$ For example, they include the word solicitor in the first category although it can have more than one meaning outside law.

9 The total number of entries and subentries under letter "P" is 4645 . There are 784 one-word terms, 3210 multi-word terms. Latin terminological phrases (576) as well as abbreviations and acronyms (75) were excluded from calculation.
} 
nomenclatures as natural or exact sciences may do; law as any other human science is based on abstract concepts and culturally rooted institutions sometimes expressed in language acquiring its terminological specificity only in a particular context.

To illustrate this task the text extracted from a Canadian manual instructing young lawyers how to get ready for their first performance as counsel ${ }^{10}$ suggests a possible analytical approach:

\section{Example 1}

The most important step in the pre-trial process is the oral examination of each party under oath. The transcript of the examination of the opposing party may be read into the trial record. The purpose of an examination for discovery is:

(1) to obtain admissions which help you to prove your case;

(2) to obtain admissions which will undermine your opponent's case;

(3) to discover the evidence upon which your opponent relies to establish his case;

(4) to narrow the issues to be determined at trial.

The underlined lexical units constitute legal terms belonging to the second category described earlier, i.e. legal terminology found in other branches of knowledge and possibly in everyday communication (although not necessarily precisely understood by commoners). What matters here is identification by the translator whether the same concepts exist in the target legal system and whether the target language may provide suitable terminological equivalents. Considering the distinction between common law as the source law in this text and any continental legal system, special "translational" attention should be paid to discovery ${ }^{11}$ and admissions as these concepts may be missing in continental civil procedures. Transcript, oath or opponent are formal words rather than legal terms. Regard should also be given to all collocations with case: in all three occurrences case does not mean the whole cause or suit brought before court but just an individual representation of facts and grounds by one party and should be translated accordingly. Finally, the phrase to establish his case belongs to legal jargon rather than statutory language and means to prove or substantiate one's allegations.

A traditional core objective of translation has been to reach equivalence between the source text and the target text. As the focus of translational theories has shifted from the strong orientation on the source text to emphasising the purpose of translation, which may determine the mode and process of a translator's work, the understanding of equivalence has also slightly modified. We may speak of equivalence at all levels of a text - lexical units, phrases, sentences, paragraphs and the text as a whole, but a question arises whether the translator may seek equivalence at a higher level, such as discourse; for example, a British letter of claim (formerly called statement of claim), no matter how excellent the translator's translation into Czech may be, can never be used for the commencement of a civil action before a Czech court as neither the formal nor substantive elements required by Czech law would be preserved. Should the issue of translational equivalence be reduced to legal vocabulary the degree of equivalence

\footnotetext{
${ }^{10}$ Stockwood, David, Q.C. 1980. Civil Litigation. A Practical Handbook. Toronto: The Carswell Company Limited, p. 51.

${ }^{11}$ In British contexts, the term discovery as defined by the Rules of the Supreme Court 1965 (Order 24) was replaced by disclosure (Civil Procedure Rules, 31).
} 
should always be measured in the legal context of the target text in which a particular terminological equivalent is to be used; for example, an information, criminal complaint and indictment are documents instituting criminal proceedings in the US but which of them should be chosen as a proper legal equivalent in translation into English should the source criminal law have just one such document containing some features of each of them? Or what equivalent should be used for arraignment if there is no such legal institution in the target law?

Attaining equivalence in the translation of legal terms should go with conceptual analysis of a particular term; translation may require not only a comparative conceptual analysis of the source term and its potential equivalent in the target language and/or legal system but also a comparative research into a wider (extra-linguistic and possibly extralegal) context. Šarčević (2000: 238) distinguishes among three basic degrees of equivalence: (a) "near equivalence", where concepts in the source language and target language expressed by the respective terms share all of their essential elements and most of their accidental characteristics; (b) "partial equivalence", where concepts in the source language and target language share most of their essential elements and only some of their accidental characteristics; and (c) "non-equivalence", where concepts in the source language and target language share a few or none of their essential elements and no accidental characteristics. Whilst the first two types of equivalence could be satisfied with a functional or substantive equivalent in the target law, non-equivalence (e.g. the above mentioned example of arraignment) would be compensated for by an explanatory or descriptive equivalent (cf. Zgusta 1971: 319 or Al-Kasimi 1983: 159).

\section{Synonymy in legal terminology}

\subsection{Propositional synonymy}

Whilst equivalence is the ultimate concept in translation between languages, synonymy is the relationship established between or among units within one language and as such it can play an important role in intralanguage translation or interpretation mentioned above.

Synonymy is traditionally bound to the relations between lexical units but syntactic units may feature similar characteristics, the former being termed lexical synonymy and propositional synonymy is used for the latter. Propositional synonymy is sometimes referred to as paraphrase (e.g. Murphy 2008: 144). Although our focus is on lexical synonymy applicable to legal terminology, propositional synonymy can be found in various legal contexts:

\section{Example 2}
A. "... unless the contract provides otherwise"
B. " $\ldots$ in the absence of a provision to the contrary"
C. "... except when otherwise provided by the contract" 
These three phrases have the same meaning, suggesting that whatever has been expressly agreed upon, or has been implied by contracting parties, will apply as long as there is no explicit statement (in the law) overriding it. Since the meaning is more relevant for translation than the syntactical form of the phrases, they all can be translated by one phrase in the target language that best reflects in the target law the message contained in the source language phrase.

\section{Example 3}
A. "You do not have to say anything unless you wish to do so, but what you say may be given in evidence."
B. "You have the right to remain silent. If you give up the right to remain silent, anything you say can and will be used against you in a court of law."

These two statements of the police caution are geographically differentiated paraphrases, A applicable to the United Kingdom, B used in the USA as the initial part of Miranda warning, but these distributional constraints (Saeed 2003: 66) seem to be irrelevant for translation.

Individual segments of both warnings may be cut into three logical parts and compared.

\begin{tabular}{|l|l|l|}
\hline \multicolumn{1}{|c|}{ A } & \multicolumn{1}{|c|}{ B } \\
\hline 1. & $\begin{array}{l}\text { You do not have to say } \\
\text { anything }\end{array}$ & $\begin{array}{l}\text { You have the right to remain } \\
\text { silent. }\end{array}$ \\
\hline 2. & unless you wish to do so & $\begin{array}{l}\text { If you give up the right to } \\
\text { remain silent, }\end{array}$ \\
\hline 3. & $\begin{array}{l}\text { but what you say may be } \\
\text { given in evidence. }\end{array}$ & $\begin{array}{l}\text { anything you say can and will } \\
\text { be used against you in a court } \\
\text { of law. }\end{array}$ \\
\hline
\end{tabular}

Not only do the cautions as a whole have the same meaning (despite their different syntactical structure) and are understood in the same way in the UK and US respectively, but their individual parts, if separated, can be seen as paraphrases of each other: A1 and B1 can be freely swopped; A2 and B2 cannot be used interchangeably in these two cautions due to the initial verbal negation in A1; A3 and B3 might be interchanged still preserving the meaning although one may think about nuances in procedural equivalence of "be given in evidence" versus "be used against you in a court of law". Technically speaking, the latter presupposes the former.

\subsection{Lexical synonymy}

The extent of similarity or sameness in meaning between lexical units differs and three factors are usually discussed - the scope of similarity or resemblance, permissible or acceptable differences and the distributional potential of alleged synonyms; one factor not always emphasized is context that, pragmatically, has a decisive impact on determining the meaning of a lexical unit or units. Murphy (2008: 145) speaks about sense relation rather than word relation (cf. Malmkjaer's sense-based and word-based 
translation above) since what matters are individual traits of meaning that are compared; we maintain her argument that "synonymy is a relation between words in use" as context-dependence is a crucial factor in determining the identity of senses particularly in legal terminology.

Linguistic terms designating this fluctuating degree of sameness/similarity vary. Cruse (1991: 265-295) distinguishes among absolute synonyms having their semantic mode identical (i.e. all their propositional, expressive and contextual traits), cognitive synonyms sharing most important (or "central" in Cruse's terminology) traits but having various collocational or contextual restrictions, and plesionyms ${ }^{12}$ which normally may be considered cognitive synonyms but are used in a sentence stressing their different subordinate semantic traits tending to deny their potential as synonyms; plesionyms very often hinge on hyponymy as suggested in the example provided by Cruse (286): "Was he murdered?" "Not exactly - but he was killed." The trio of an information, criminal complaint and indictment can also be assigned to the category of plesionyms in some contexts.

Jackson\&Zé Amvela (2007: 107-113) distinguish between strict and loose synonymy (the latter covering Cruse's cognitive synonyms and plesionyms) pointing out that the former is uneconomical because it creates unnecessary redundancy in a language. Löbner (2002: 46) speaks about total and partial synonyms, the former having all meaning parts identical (descriptive, social and expressive meaning), the latter sharing just some and to a various extent.

Filipec\&Čermák (1985: 133) emphasize that two aspects should be considered in identifying the extent of sameness or similarity: (a) the intension (as the internal content of a notion or the sum of the attributes contained in it, i.e. its meaning parts) which can be identical or variant, and (b) the distribution of synonyms. Where synonyms are identical with respect to both intension and distribution, full (or 'exact') synonymy occurs; there will be partial (or 'loose') synonyms in all other cases. The latter prevails in occurrence. Should we admit that full synonymy exists in the lexis of law it would always be confined to a particular legal (and linguistic) context; only exceptionally there are synonyms which may be used interchangeably in all leg al contexts, such as causal link, causal nexus or causal connection.

Sameness/similarity can be a relevant factor in translation when prescriptive and descriptive terms are considered and their equivalents in the target legal system are sought having the same degree of normativity. Legal discourse can be subdivided into three major (but multifarious) areas according to the prescriptive or descriptive nature of speech acts, namely the language of legislation being highly prescriptive, the language of judgments depicting both prescriptive and descriptive features, and the language of legal representation, which is primarily descriptive (Knapp,1995: 120). Terminology used in individual areas follows the same pattern: (a) prescriptive terms are defined by and contained in statutes; in common law there are also terms developed through case law and conventions; and (b) descriptive terms as lexical units featuring a certain degree of contextual legal and linguistic specificity and used in everyday legal practice including professionalisms as a part of legal jargon (cf. Galinski 1982: 189 and Tiersma 1999: 109). Generally speaking, a descriptive term can never be a full synonym for its

\footnotetext{
${ }^{12}$ From Greek: plesio- means "near".
} 
prescriptive counterpart as their distributional characteristics differ (although their intension may be identical or very close). The question arises whether translation of a prescriptive term in the source text with a descriptive term in the target language falls within the ambit of near or partial equivalence (cf. Šarčević above), i.e. whether the type of discourse where a particular terminological unit is used should be considered its conceptual essential element, or whether it is reduced to its accidentals, and the difference in its distribution would diminish its degree of equivalence. The following example provides one prescriptive term and its three descriptive counterparts.

Identification of the nature of terminological synonyms would be the crucial issue for a translator to find their adequate equivalents in the target legal system.

\section{Example 4}

Lapse of time or statute of limitation clauses are prevalent as well. ... Under some treaties the applicable law is that of the requested state, in others that of the requesting state; under some treaties extradition is precluded if either state's statute of limitations has run. When a treaty provides for a time-bar only under the law of the requesting state, or only under the law of the requested state, United States courts have held that time-bar of the state not mentioned does not bar extradition. Left unsaid is the fact that some treaties declare in no uncertain terms that the passage of time is no bar to extradition.

Statute of limitation is a "pure" prescriptive common law term denoting the concept (or the legal institution) dating back to the Roman Empire. Lapse of time and time-bar are used in various legal settings and as such form descriptive terms with the same intension (meaning components) as statute of limitation. Unlike lapse of time, which is an established terminological unit, passage of time attains certain intensional terminological characteristics only in the co-text and context above. However, all four terminological synonyms denote the same concept; the translator should look for the same concept in the target legal system, then for its terminological denotation and potential (full or partial) synonyms; subsequently, he would identify the degree of equivalence between synonyms in the source text and their potential matches in target law. Czech law, for example, has just one prescriptive term promlčeni that would be used in all four occurrences should the text above be translated into Czech; any translational "creativity" may lead to interpretive difficulties.

\subsection{Synonymical chains}

A special feature of common law terminology hinging on synonymy is an extensive usage of terminological doublets, triplets and synonymical chains; although doublets and triplets differ from synonymical chains in that the former represent more or less stable combination of two and three terms respectively and the latter may be combined ad hoc to serve a particular legal context, they all are a series of synonyms whether linking two, three or more lexical units having the same or similar meaning serving the special (and intended) purpose of making the sense of the utterance as clear as practicable and its interpretation as unequivocal as possible. As Garner (1995: 292) notes "amplification by synonym has long been ... a part of the language of law" tracing its beginning back to the English Middle Ages and Renaissance when "synonymia was a common figure of 
speech." One reason for using such paired or multiplied synonyms historically subsisted in their rhetorical specialty but the other, and more significant, reason has been lawyers' striving to arrange for as precise and accurate understanding of their statements as possible, which sometimes invokes the opposite effect. Phillip, academic jurist and practising lawyer, in his comment on legal terminology states (2003: 154): "Typical of the legal text, more a quirk than a characteristic, are the near-synonyms clustering around these [dispone, bequeath, consent] performative terms." Needless to say, the translator should always be alert should he or she find a chain of apparently synonymical lexical units in the source English text originating in common law. Not much problem is caused by prepositional doublets such as by and between or by and with since prepositions collocate with particular functional words usually in a different way in the source language and in the target language; the choice of TL prepositions will be directed by TL equivalents of SL functional words. However, a chain of synonymical verbs, nouns or their combination may pose a dilemma for the translator whether to transmit to TL all elements in the chain and to what extent such transmission may be bound by the meaning of the chain as a whole and not by its individual components. The following examples will be analysed from the translator's perspective.

Classical specimens of doublets composed of full synonyms which may be freely translated by one TL equivalent are not very numerous in common law English. Example 5 illustrates three different occurrences (A, B, and C) of verbal doublets.

\section{Example 5}

A. This Loan Agreement ("Agreement"), made and entered into on this fifth day of October, 1997, and made effective as of October 13, 1997.

Phrases to make an agreement and to enter into agreement have fully identical meaning suggesting that parties have created their relationship and imposed enforceable obligations upon each other. These two phrases have been elliptically combined into one verbal doublet preserving the meaning of its components; therefore a TL equivalent formed by one verb only is a must where the target legal system does not possess terminological verbal synonyms for this particular act of forming a contract.

B. This instrument is to be construed and interpreted as a general power of attorney.

Generally speaking, to construe a text requires the same mental activities to be pursued as are done with to interpret a text. These two verbs very often serve their mutual dictionary explanations. Most lawyers admit that these two verbs, as well as their nominal derivatives construction and interpretation have identical meaning in their practical applications, i.e. they are full synonyms; however, there are jurisprudential contexts, such as various theoretical approaches to statutory interpretation where interpretation is confined to individual provision of a statute whilst construction applies to the statute as whole. Again, where the target legal system is free of such synonyms the only option for the translator would be to use just one TL equivalent.

Partial synonyms have already been mentioned. The following use of restrict and limit may serve as illustration of their practical application. 
C. The failure to enumerate a specific item, power, or authority does not restrict nor limit my attorney-in-fact from doing them.

Comparing the dictionary definitions (Black's Law Dictionary $9^{\text {th }}$ ed.) of restrict (to limit or qualify) and limit (to restrict or restrain) suggests that there is a marginal difference in their meaning. However, their distribution, and the distribution of their derived words (nouns, adjectives and participles) may slightly differ in various legal contexts as they are not commonly exchangeable. Here the translator may use a TL paraphrase of "does not restrict in any manner ...".

More complex doublets and synonymical chains are illustrated by the following examples.

\section{Example 6}

Seller further warrants to Buyer that Seller will fully defend, protect, indemnify, and hold harmless the Buyer and Buyer's lawful successors and assigns from any adverse claim thereto.

The underlined synonymical chain splits into two parts: defend, protect and indemnify and hold harmless. Whilst in the former pair most languages can freely find their legal equivalent for either SL term and the translator may use them accordingly, the latter pair is more controversial for translation. The verb indemnify has a triple definition according to a particular context: 1 . to reimburse someone for a loss suffered because of a third party's or one's own act or default; 2. to promise to reimburse for such a loss; 3 . to give security against such a loss. Each number designates a different degree of solving the consequences of a loss, from a direct payment in one, through committing oneself to pay in two, to pledging property or money to substantiate the intent to pay should a loss occur in three. The phrase to hold harmless means "to absolve (another party) from any responsibility for damage or other liability arising from the transaction". Although this definition fully corresponds with just the first meaning of indemnify we tend to claim that the consequences of both situations - indemnify in its triple meaning and hold harmless - are identical as no expenditures resulting from an adverse claim against the object of the sale may be incurred by the Buyer and should they be the Seller must reimburse the Buyer. In this sense the two terminological units may be translated by one TL equivalent where the target law seems to be deficient in synonyms for the same legal institution.

\section{Example 7}

I grant to my attorney-in-fact the full |power and authority| to |do and perform| |all and every $\mid$ act and thing $\mid$ required and proper $\mid$ to be done in the exercise of any of the |rights and powers| granted herein as fully as I might do.

This is the granting clause in a general power of attorney serving here as an etalon of what Garner calls "ritual language" (1995: 294). The clause is composed of 44 words of which 18 form doublets; and each doublet has no other role but to convey the serious and solemn character of the clause as it is to notify third parties of the relationship between the principal and the agent. Although each doublet may be reduced to only one TL equivalent the discursive role of a power of attorney in the target legal system may require a similar ceremonious form of the target (ritual) language. On the other hand, for 
example, Czech law prescribes quite a concise form of a general POA; coupling Czech synonyms for English doublets would be considered redundant and may be confusing.

\subsection{Synonyms in dictionaries}

A dictionary of synonyms or thesaurus may be a useful reference source for translating general or literary texts. Although there are legal thesauri (such as Burton's Legal Thesaurus 1998, New York: McGraw-Hill, or those provided via the Internet) a legal translator should always be aware of one principle applicable to the use of legal terminology by lawyers: they tend to see a new concept behind a new (different) term. This results in another principle applicable to the use of synonyms in legal translation: the translator should not be creative in that he or she uses as many synonyms as possible in order to make the text less boring and to show he or she can play with the language. As suggested earlier, there are not many full synonyms with the same intension (meaning traits) and distribution (potential to be used in the same contexts), causal linkcausal connection - causal nexus being repeated as an example; whatever the SL term materializing the source law concept may be, any of the triplet can be used as the TL equivalent in any context. Other strings of synonyms offered as equivalents by various translational legal dictionaries will not offer an unambiguous option.

\section{Example 8}

term - condition - warranty

These three terms are partial synonyms as their intension is usually very close to each other but there are contexts where they may not be used interchangeably and each term represents an individual concept. Essentially, a term is any provision forming part of a contract and is mostly used in plural (terms) as limiting stipulations or clauses in a contract. Terms may be either a condition or a warranty depending on their importance. The former is a term of contract under which one party is bound to do a particular thing; a failure on his or her part to perform the promised act constitutes a breach of contract and gives rise to liability for the breach. A warranty is a lesser, subsidiary term of the contract; a breach of a warranty gives rise to liability for damage caused by, for example, a defective product and as such cannot terminate the performance of the contract. It should be noted that doublet terms and conditions is among the most common redundancies in legal drafting (Garner 1995: 872). This doublet is usually used as a subheading to identify the part in a contract where all conditions are stipulated; it can be rephrased as contractual terms and translated to the TL accordingly.

\section{Example 9}

an act - a law - a statute - an ordinance - a regulation - legislation

Burton's Legal Thesaurus provides the chain of 21 (English +2 French) terms considered to be synonyms of the noun act. However close their intension may be, their distribution significantly differs. The name of a piece of legislation approved by a 
parliament will contain Act and never any other member of the string; a law is a generic term denoting any piece of legislation passed by parliament ${ }^{13}$; a statute is an original common law term distinguishing a written law passed by parliament from case law established by precedents and today can be used interchangeably with a law; ${ }^{14}$ today an ordinance denotes a municipal regulation under US law but, historically, it was any authoritative rule although of a less permanent nature than a law. A regulation ${ }^{15}$ is any express rule usually reduced to writing and issued by any competent and authoritative body (from a local council to parliament). Legislation is only an uncountable noun although it may denote the body of laws as well as an individual statute depending on the context.

\section{Polysemy in legal terminology}

Whilst synonymy hinges on the relations among lexical units, polysemy applies to one lexical unit possessing multiple meanings. In this sense, polysemy is quite close to homonymy but the origin of polysemic and homonymous words differ. Traditional understanding of homonymy (or contrastive ambiguity in Pustejovsky's understanding, 1996: 2), as opposed to polysemy (or complementary ambiguity), is that homonyms have no common etymological roots or basis whereas polysemes have developed from one common form and acquired different or modified meanings through their devolution. We would maintain Poštolková's assumption (1983: 24, 27) that terminological homonyms, should these be found, are the same lexical units having an incoherent termto-concept relation and used in different branches of science. Therefore, we argue that pure homonymy within one legal system exists in neither legal English nor legal Czech. The problem that lawyers as well as translators face is extensive polysemy resulting from a general tendency in the languages to assign new meanings to the existing vocabulary, i.e. its tendency to sense extension. A polysemous term has several shades of meaning, more or less clearly separable but with a basis in similarity (Malmkjaer 2005: 108). Riggs (1982: 160), (1993: 207), in explaining the substance of polysemy, expands the classification claiming that it is valence that denotes the type of term-toconcept relationship: when a word has one and only one meaning, it may be called univalent (or monosemic), and when it has two or more meanings it is multivalent (polysemic or polysemous); a multivalent (polysemous) term that has only one meaning within a given discourse community can be called unequivocal, whereas when it has several meanings in such a community, it is properly called equivocal. An unambiguous use of an equivocal term may be achieved where writers supply contextual clues to show which of its possible meanings is intended. The simplest contextual hint may be a premodifying classifier attached to the noun term, such as arrest warrant or share

\footnotetext{
${ }_{13}^{13}$ Except for some Australian local governments calling their community ordinances local laws.

${ }^{14}$ It should be noted, however, that Statute is also a concrete name given to a legislative instrument in Australia.

${ }^{15}$ Regulation may also be an uncountable noun expressing the process of controlling by rule or the act of regulating. Should the European Union be mentioned in this context regulation denotes a specific type of EU secondary legislation directly applicable to all EU member states.
} 
warrant instead of a sole warrant, or a postmodifying qualifier, such as writ of execution or writ of summons contextualizing the head term writ.

Identification of polysemic expressions in a legal text is difficult, if not impossible, without a sufficient knowledge of the respective legal issue and without a reasonable context available which helps delineate the topic, a branch of law, text-type, etc. For example, disposition has three (main) separable meanings in common law:

1. the act of transferring something to another's possession (e.g. testamentary disposition);

2. a final settlement of a case by court (in this sense it is more widely used in the USA; in the UK this term is usually confined to decisions of juvenile courts);

3. a provision in a statute (e.g. general dispositions).

Possibly the fourth meaning (although not very frequent) can be mentioned:

4. personal temperament of traits of character.

All four meanings will require different TL equivalents reflecting on the principles of target law; otherwise the extent of ambiguity in the target text may rise. Čermák (1995: 244) speaks of contrastive polysemy (i.e. translational or bilingual) which should be taken into account particularly by lexicographers compiling bilingual dictionaries.

\section{Example 10}

Section 1. General Dispositions

Art. 1415. Regulation by agreement among coheirs or by testamentary disposition

Meanings 3 and 1 outlined in Example 11 above are used in the heading and subheading of one provision in the Louisiana Civil Code 1996 respectively. Premodifiers will help the translator correctly interpret (and disambiguate) the meaning of either one. The meaning of the phrase general dispositions is contextualized primarily by its formal location in the text - it is placed in the heading of a longer passage of the statutory section followed by an outline of basic principles applicable; whilst the classifier testamentary precisely determines the context of the whole terminological phrase.

\section{Example 11}

If both parties to a divorce action also request the court in writing to order disposition of marital property acquired by either or both of the parties to the divorce prior to January 1, 1972 , or nonmarital property owned by the parties to the divorce action, the court shall also order disposition in accordance with subsection 1. (Maine Revised Statutes, §953. Disposition of property)

Meaning 3 applies to both occurrences of disposition in this provision, the postmodifying qualifier of (marital) property being the sense clue in any legal context. Although the translational equivalents of disposition used here and that in the phrase testamentary disposition are likely to differ, as is the case of Czech law ('nakládání' and 'poŕizení' respectively, although they are close synonyms in general Czech), the difference subsists in a "ritual" nature of the language used in last wills rather than in the dissimilarity of meaning.

\section{Example 12}

They [students] found that only legal factors, including the number of arrests and detention prior to the adjudicatory hearing, predicted final disposition; [...] 
The meaning of disposition here is the settlement of a case by court. There are several hints leading to the proper sense interpretation: the institutions of arrest, detention, adjudicatory hearing suggest the context of judicial (criminal) procedure resulting in a court decision. Moreover, the classifier final may also help discriminate meanings as final disposition is sometimes considered a terminological unit of its own.

There are many terminological polysemes used in legal English and requiring very accurate and precise choice of equivalents in the target language and legal system; some are quite famous, such as sanction meaning either an authoritative approval or penalty, homeless person being either without any place to live or without state nationality under international law, or procurement denoting either a business transaction with the state (government) or arranging for sexual services for someone else. Other are quite concealed: classifiers voluntary and involuntary in two terminological sets voluntary/involuntary manslaughter and voluntary/involuntary bankruptcy. The classifier in the former terminological phrase denotes that the killer was either aware of what he or she was doing and of the consequences of such act (voluntary manslaughter) or he was not and the act was committed for example by accident; the latter terminological set suggests that the petition for a bankruptcy order is filed either by the debtor (voluntary petition) or by the creditor (involuntary petition). Target language equivalents should reflect on similar legal concepts in the target legal system (conceptual or functional equivalents); if they are missing the translator should use an explicative approach.

\section{Conclusion}

The specificity of bijural translation subsists in that it belongs to a wider category of intersemiotic translation: one dual semiotic system (source language expressing source law) is transferred into another dual semiotic system (target language expressing target law). The cultural rootedness of both the language and the law means that full, or absolute, equivalence between the two dual semiotic systems (as well as between the source legal texts and the target legal text) can hardly be found, or even approximated. The meaning of a legal term, whether mononymous or multiverbal, monosemous or polysemous, unique or member of a synonymical string, is context-dependent; its identification depends on the translator's knowledge of source law, and the choice of its equivalent in the target language is fully dependent upon the translator's knowledge of target law. In other words, translator's bijural literacy is a decisive factor in his competent use of legal synonyms and correct identification of polysemous terms.

\section{References}

Al-Kasimi, Ali M. 1983. “The Interlingual/Translation Dictionary.” In: Lexicography: Principles and Practice, edited by R. R. K. Hartmann, 153-162. London: Academic Press.

Čermák, František, Blatná, Renata (eds.). 1995. Manuál lexikografie. Praha: H+H. 
Chromá, Marta. 2008. "Translating terminology in arbitration discourse.” In: Legal Discourse Across Cultures and Systems, edited by Bhatia, V., Candlin, Ch., Engberg, J., 309-327. Hong Kong: Hong Kong University Press.

Cruse, D. Alan. 1991. Lexical Semantics. Cambridge: Cambridge University Press.

De Groot Gerard-René, Van Laer Conrad J.P. 2006. "The Dubious Quality of Legal Dictionaries." International Journal of Legal Information, Vol. 34:1, 65-86.

De Groot Gerard-René, Van Laer Conrad J.P. 2008. The Quality of Legal Dictionaries: an assessment. Maastricht Working Papers, Faculty of Law 2008/6.

De Groot, Gerard-René. 1987. "Problems of legal translation from the point of view of a comparative lawyer (seven theses for the $\mathrm{XI}^{\text {th }}$ World Conference of Federation Internationale des Traducteurs)." Van taal tot taal, Vol. 31, No. 4 (1987), Hilversum: Nederlands Genootschap van Vertalers, 189.

Filipec, Josef, Čermák, František. 1985. Česká lexikologie. Praha: Academia (Studie a práce lingvistické).

Galinski, Christian. 1982. "Standardization in Terminology - an Overview." In: Terminologies for the Eighties, Infoterm Series 7, edited by W. Nedobity, 186-226. Munich: K. G. Saur.

Garner, Bryan. 1995. A Dictionary of Modern Legal Usage. Oxford, New York: Oxford University Press.

Halliday, M.A.K., Teubert, Wolfgang, Yallop, Colin, Čermáková, Anna. 2004. Lexicology and Corpus Linguistics. London, New York: Continuum.

Hoey, Michael. 2006. Lexical Priming. London, New York: Routledge..

Hughes, Brian - Alcaraz, Enrique. 2002. Legal Translation Explained. Manchester: St. Jerome Publishing.

Jackson, Bernard. S. 1985. Semiotics and Legal Theory. Deborah Charles Publications, (reprinted 1997).

Jackson, Howard, Amvela, Etienne Zé. 2007. Words, Meaning and Vocabulary. An Introduction to Modern English Lexicology. London, New York: Continuum.

Jakobson, Roman. On Linguistic Aspects of Translation. 1959. In: On Translation, edited by R. A. Brower, 232-39. Cambridge, MA: Harvard University Press, [Reprinted in Venuti 2003].

Jakobson, Roman. 1960. "Closing Statement: Linguistics and Poetics." In: Style in Language, edited by Sebeok, T., 350-377. Cambridge MA: MIT Press, 1960.

Knapp, Viktor. 1995. Teorie práva. Praha: C. H. Beck.

Lando, O. - Beale, H. (eds.). 1995. Principles of European Contract Law. Dordrecht: Nijhoff.

Lando, O. - Zimmermann, R. - Bar, V. C. 2002. Principles of European Private Law. $2^{\text {nd }}$ ed., Dordrecht: Nijhoff.

Löbner, Sebastian. 2002. Understanding Semantics. London: Arnold, Hodder Headline Group.

Malmkjær, Kirsten. 2005. Linguistics and the Language of Translation. Edinburgh: Edinburgh University Press.

Mellinkoff, David. 1963. The Language of the Law. Eugene, OR: Resource Publications, (reprint 2004).

Murphy, M. Lynne. 2008. Semantic Relations and the Lexicon. Cambridge: Cambridge University Press. 
Nord, Christiane. 1991. Text analysis in translation. Amsterdam / Atlanta: Rodopi, 1991.

Pearson, Jennifer. 1998. Terms in Context. Amsterdam: John Benjamins Publishing Company.

Phillips, Alfred. 2003. Lawyer's Language. How and why legal language is different. London: Routledge.

Poštolková, Běla, Roudný, Miroslav, Tejnor, Antonín. 1983. O české terminologii, Praha: Academia.

Pustejovsky, James, Boguraev, Branimir. 1996. Lexical Semantics. The Problem of Polysemy. Oxford: Clarendon Press.

Riggs, Fred. W. 1982. "Descriptive Terminology. Its Relevance for the Social Sciences." In: Terminologies for the Eighties, Infoterm Series 7, edited by W. Nedobity, 144160, Munich: K. G. Saur.

Riggs, Fred. W. "Social Science Terminology: Basic Problems and Proposed Solutions." In: Terminology: Applications in Interdisciplinary Communication, edited by H. S. Sonneveld, K. L. Loening, 195-220. Amsterdam: John Benjamins Publishing Company, 1993.

Riley, Alison. "The Meaning of Words in English Legal Texts: Mastering the Vocabulary of the Law - A Legal Task." Law Teacher 29-30, 68-83. London: Sweet and Maxwell, 1995.

Saeed, John I. Semantics. $2^{\text {nd }}$ ed. Oxford: Blackwell Publishing, 2003.

Šarčević, Susan. New Approach to Legal Translation. The Hague, London, Boston: Kluwer Law International, 2000.

Sinclair, John. "Language and computing, past and present." In: Evidence-based LSP. Translation, Text and Terminology edited by Ahmad, K., Rogers, M., 21-52. Bern: Peter Lang, 2007.

Thomas, Patricia. "Choosing Headwords from Language-for-Special-Purposes LSP. Collocations for Entry into a Terminology Data Bank. Term Bank.” In: Terminology: Applications in Interdisciplinary Communication, edited by H. S. Sonneveld, K. L. Loening, 43-68. Amsterdam: John Benjamins Publishing Company, 1993.

Tiersma, Peter M. Legal Language. Chicago and London: The University of Chicago Press, 1999.

Tomášek, Michal. 1991. "Právo - interpretace a překlad.” Translatologica Pragensia V, Acta Universitatis Carolinae Philologica 4-5/1991. Praha: Karolinum, 147-154.

Trosborg, Anna (ed.). Rhetorical Strategies in Legal Language. Discourse Analysis of Statutes and Contracts. Tubingen: Gunter Narr Verlag, 1997.

Venuti, Lawrence. The Translation Studies Reader. London: Routledge, 2003.

Widdowson, Henry G. Explorations in Applied Linguistics. Oxford: Oxford University Press, 1979.

White, James Boyd. Justice as Translation. An Essay in Cultural and Legal Criticism. Chicago, London: The University of Chicago Press, 1994.

Zgusta, Ladislav. Manual of Lexicography. Praha: Academia, The Hague: Mouton, 1971. 